Portland State University

PDXScholar

\title{
Interinstitutional Library Collaboration: Support for a Joint Master of Public Health Program
}

\author{
Emily Ford \\ Portland State University, forder@pdx.edu \\ Laura Zeigen \\ Oregon Health \& Science University
}

Follow this and additional works at: https://pdxscholar.library.pdx.edu/ulib_fac

Part of the Library and Information Science Commons

Let us know how access to this document benefits you.

\section{Citation Details}

Ford, Emily and Zeigen, Laura, "Interinstitutional Library Collaboration: Support for a Joint Master of Public Health Program" (2013). Library Faculty Publications and Presentations. 133.

https://pdxscholar.library.pdx.edu/ulib_fac/133

This Post-Print is brought to you for free and open access. It has been accepted for inclusion in Library Faculty Publications and Presentations by an authorized administrator of PDXScholar. Please contact us if we can make this document more accessible: pdxscholar@pdx.edu. 
Inter-Institutional Library Collaboration

Inter-Institutional Library Collaboration: Support for a Joint Oregon Master of Public Health Program

Emily R. Ford ${ }^{\mathrm{a}}$ and Laura Zeigen ${ }^{\mathrm{b}}$

${ }^{\text {a} B r a n f o r d ~ P . ~ M i l l a r ~ L i b r a r y, ~ P o r t l a n d ~ S t a t e ~ U n i v e r s i t y, ~ P o r t l a n d, ~ O R, ~ U S A ~}$

${ }^{\mathrm{b}}$ Library, Oregon Health \& Science University, Portland, OR, USA 


\begin{abstract}
:
Library-related and resource access issues confronting students enrolled in an inter-institutional joint master's degree program in public health are addressed in this chapter. It details a crossinstitutional collaborative effort to identify and provide research resources to inter-institutional joint degree students and faculty and analyzes the program through the lens of literature on collaboration in higher education and in library instruction. Reports on findings from qualitative feedback and quantitative card sort analysis data were gathered to inform development of content for, and organization of, a library research guide. Bureaucratic structures and policies often affect library services to students and faculty in inter-institutional joint degree programs. Therefore more salient information about library policies, services, and resources was needed in order for the affected libraries to coordinate instruction, collections, and services to best support such programs. One of the limitations of the case study was that limited qualitative and quantitative feedback was received. Also there was no prior formal needs assessment. Nevertheless, the chapter provides insight to challenges facing libraries and librarians supporting inter-institutional joint degree programs. It also points to administrative opportunities to create rich library collaborations. Existing literature does not adequately address obstacles of in-person interinstitutional joint degree programs. The contribution of this chapter is that it identifies the complications of access, library policies, and administrative procedure that will need to be address by two or more libraries that want to support joint degree programs at the college or university level.
\end{abstract}

\title{
Keywords:
}

Library instruction, collaboration, joint degree programs, research guides, card sort analysis, LibGuides

Paper classification: Case study 


\section{Introduction}

Collaborative work is a growing trend in higher education. Within universities, departments and schools are collaborating on research projects, funding proposals, and other initiatives. There are also collaborations between institutions and communities, and cross-institutionally. Although much collaboration is informal, the number of formal collaborations forming between institutions of higher learning is increasing. Joint degree programs are only one such example. They offer many rich opportunities to institutions of higher education and have a number of positive outcomes: expanding research capabilities, enriching subject expertise, leveraging preexisting informal collaborations, and providing social and political benefits to the institutions involved (Denecke, Kent, Anderson \& Council of Graduate Schools, 2010; Michael \& Balraj, 2003).

Despite the rich learning and research environments of such degree programs, they also pose some unique administrative challenges. Different matriculation guidelines and systems, course offerings and locations, and internal institutional barriers are examples of these challenges. Other challenges to joint programs as discussed by Michael and Balraj (2003) can include: leveraging of resources, institutional ownership, governance structures, and institutional oversight from state government.

Joint degree programs can take many forms. Michael \& Balraj (2003) identified three distinct models of joint degree programs:

- joint degree programs;

- dual degree programs; and

- joint dual degree programs (pp. 138-139).

These programs may exist at one or between many institutions. They defined joint degree programs as "...a single degree program jointly offered by two separate institutions" (p. 138), which is the definition used in this chapter. Although some benefits and challenges to joint degree programs have been identified herein, there is a paucity of literature and research on the topic.

In the following sections, background is provided to set the context for the cooperating libraries to provide support services to an inter-institutional Oregon Master of Public Health $(\mathrm{OMPH})$ program involving three universities - Oregon Health \& Science University (OHSU), Oregon State University (OSU), and Portland State University (PSU). A brief description of the program is followed by how two of the three libraries identified student and faculty needs, and developed joint support services such as a library research guide for student and faculty in Portland.

\section{The Joint Program}

The OMPH program is accredited by the Council on Education for Public Health and according to the OMPH website, was ranked the OMPH program number 2 for graduate schools in the discipline of Community Health in 2003 (Oregon Master of Public Health, 2009) by US News \& World Report. During the 2010-2011 academic year 105 students enrolled in the program through OSU, 167 through PSU, and 135 through OHSU. At each of these institutions the majority of students are enrolled part-time. OSU had 67 full-time students, PSU had approximately 60, and OSHU had 51. Both OHSU and PSU are located in Portland, OR and situated only two miles apart. OSU is 90 miles away in Corvallis, OR. The latter will separate 
Inter-Institutional Library Collaboration

from the OMPH program in 2012 since it received accreditation for its own School of Public Health. It is therefore not described in detail.

OMPH students enroll in one of 8 tracks of study at a home institution. Each track requires 16 credit hours of core course work. Elective and total credits required to complete each track varies from 58 to 62 required credit hours. Students may fulfill their core requirements and electives at any of the three institutions.

TAKE IN TABLE 1

\section{The Context}

\section{Portland State University}

PSU is a large, urban university that began as an extension center to educate WWII veterans. It offers bachelors, masters, and doctoral degrees in all of the university's colleges and is internationally recognized for its research and educational programs in Urban Planning and Sustainability. Its motto, "Let knowledge serve the city" speaks to the institution's importance to the fabric of the Portland community. According to Portland's State Office of Institutional Research (2010) $41 \%$ of its 29,703 students are enrolled part-time, with $40 \%$ of its undergraduates aged 26 or over and $21 \%$ of graduate students aged over 40 . PSU is Oregon's largest university with a highly diverse student body. At last report (2011) the university employed 1564 instructional faculty members, 888 of which were full-time and 676 were parttime.

\section{Oregon Health \& Science University}

OHSU is the state's only health sciences university, offering diverse programs in bench sciences allopathic medicine for medical doctors, physician assistants, nurses, dentists, and allied health programs. It has 2,802 students in OHSU degree programs, and 456 students in joint programs with other universities (Oregon Health \& Science University, 2011). The student body consists predominantly of Caucasians. There are almost 14,000 faculty and staff members at OHSU.

\section{Joint Programs and Collaboration}

Joint ventures between the three schools are not limited to the OMPH. Others include a joint MBA in Healthcare between PSU and OHSU, and a School of Pharmacy shared between OHSU and OSU. A Collaborative Life Sciences building, slated to open in 2013, will house teaching laboratories, classrooms, lecture halls, and other facilities to support the teaching and learning of life sciences for OHSU, PSU, and OSU.

Oregon institutions are good examples of the growth of collaboration in higher education. Kezar and Lester (2009), discuss organizational structures that must evolve in order to create successful collaborations. Despite its focus on internal collaborations between academic affairs and other bodies within a single institution, much can be learned from the work about interinstitutional collaboration. They assert that "Learning communities and student and academic affairs partnerships struggle to become institutionalized because higher education institutions are generally organized in departmental silos and bureaucratic or hierarchical administrative structures" (p. 5). PSU and OHSU are no exception. Despite internal organizational and organizational culture barriers, the universities continue to pursue cooperative efforts. 
The environment in which OHSU and PSU work together is framed by a strategic alliance, which was officially formed in 2011. Prior to the strategic alliance, there had been movement in the state legislature to merge the institutions into one public corporation. This proposed merger was deemed unfeasible by the Learning Alliance for Higher Education (2007), citing obstacles stemming from differences in: scale, governance and growth; mission; culture; business model; and envisioned futures. After the failure of a merger, the OHSU/PSU Strategic Partnership Task Force was formed. It issued a report "to make recommendations on how the two universities can best work together to leverage state resources and meet educational needs in the Portland region and Oregon as a whole" (2011, p. 2). The report recommended the two institutions formalize their partnerships by developing a "strategic alliance with a clear business model to encourage, facilitate, and monitor future collaboration" (p.2). The task force aimed to leverage the strength of the existing collaboration with the OMPH program, pushing the institutions to: "Pursue the formation of a new, collaborative school of Public Health" (p.2). While it has not yet been formed, it is being considered by the OHSU-PSU Strategic Alliance Advancement Committee as of mid-2012.

The historical framework of higher education in the U.S. influences collaborative efforts. Kezar and Lester (2009) noted that "...the structures and cultures that emerged support and reinforce individualized rather than collaborative work" (p. 22), and fall into siloed structures where horizontal communication rarely occurs. Kezar and Lester state that reward systems "overwhelmingly support individualistic work" (p. 28) collaborative efforts become ancillary.

The expectations of traditional academic disciplines are not substituted by collaborative work. Faculty must fulfill responsibilities in their departments as well as in the context of the collaboration...Therefore, disciplinary and department structures instantiate rewards within these processes by making work outside of them mostly unvalued and unrecognized (p. 29).

There also exists an inherent clash between academic faculty and administrative cultures. Where academic faculty focus on scholarship and engage in faculty governance, Kezar and Lester assert "...they are often disconnected from larger institutional priorities" (p. 31). In this way, instituting collaborative projects and programs face big challenges.

On some levels, both OHSU and PSU experienced issues related to the siloed and individualistic nature of higher education. An example was OHSU's undertaking of a merger between the public hospital with the research university. As a result, the institution still struggles with organizational effectiveness and culture clashes between its clinical side and the research and teaching operations. What's more, the institution has deeply rooted organizational silos within its schools. For example, OHSU's academic calendars for the Schools of Nursing, Medicine, Dentistry, and Pharmacy, are not synchronized. However, the institution is working to better synchronize their calendars by the time the Collaborative Life Sciences building opens in 2013. PSU also mirrors the historical individualistic model of higher education, despite the giant leaps and bounds it makes in regards to collaboration. Faculty governance at Portland State is strong. Yet, the administration moved to a performance-based budget model beginning in FY 2013, which further incentivized and rewarded individualistic and siloed work in the departments and schools.

Based on their study, Kezar and Lester (2009) offer a three-stage developmental model of collaboration in higher education. It includes: “...1) building commitment, 2) commitment, and 3) sustaining commitment" (p. 215). Each stage contains the elements listed in Table 2.

TAKE IN TABLE 2 
OHSU and PSU are somewhere between stages one and two: building commitment, and commitment. Although administrations have vocalized commitment (stage 2) to building a strategic alliance, they must work to create shared values, rewards and missions. Certainly many informal collaborations and partnerships already exist between the two institutions in terms of research; yet, formal collaboration efforts are occurring in a "top down" manner.

While the literature of higher education administrators does not does point to library issues as a major factor, the PSU library has been informed by the administration that library issues have been made a priority for the OHSU/PSU Strategic Alliance Advisory Committee. It is interesting to note that the Council of Graduate Schools 2010 report, Joint Degrees, Dual Degrees, and International Research Collaborations (Denecke, Kent, Anderson \& Council of Graduate Schools, 2010) does not make one mention of library cooperation in its 100 pages. Michael and Balraj (2003) make only a passing comment about library resources for joint degree programs. In some ways administrative bodies at OHSU and PSU are ahead of others in terms of considering library needs for inter-institutional joint degree programs.

Be that as it may, there still exist numerous institutional challenges, as the two schools more forward with their Strategic Alliance. As of May 2012, the OHSU-PSU Strategic Alliance Advisory Committee's Implementation Committee Report indicated they were still working to "remove barriers to other collaborations" (slide 6). Building successful collaborations takes time and planning, and there is evidence that the institutions are working to build a successful alliance.

\section{Impact on Libraries}

Collaboration comes easily to the librarians involved with the OMPH in Portland. Both are faculty members at their respective institutions and both libraries are members of the OrbisCascade Alliance, a library consortium serving just under 40 private and public universities and colleges in Oregon, Washington, and Idaho.

While librarians supporting inter-institutional programs should work to clarify library policies and resource availability, it is as equally important that these librarians receive administrative support. Hope and Peterson (2002) queried librarians involved collaborative projects to ask "... what library administrators could do to promote and encourage these efforts. Three key issues emerged: support, advocacy, and leadership" (p. 33). Likewise, Alleyne, and Rodrigues (2011) point to strong administrative support for their collaborative work as contributing to their success. Similarly, Pival and Johnson (2004) indicate that rotating joint degree program administration can pose barriers to library instruction efforts, implying that administrative support for library involvement should come from library administrators as well as program administrators. The libraries at OHSU and PSU are lucky to have the support of University Librarians, Provosts, and OMPH administrators for the joint venture.

\section{Collaboration in Information Literacy}

Collaboration in support of information literacy is not new. Hope and Peterson (2002) outline three types of information literacy collaboration in academic libraries:

(1) national collaborative efforts through professional organizations, (2) multi-type, local cross-institutional collaborations, such as K-12/academic library partnerships, and (3) cross-institutional collaborative efforts between peer institutions, which often build upon pre-existing relationships, such as programs between institutions within a system or consortium (p. 23). 
With the exception of TILT (Texas Information Literacy Tutorial), most examples of collaborations in information literacy in the literature point to collaborations in support of distance learning programs and/or international collaborations. In discussing a joint distance program in Canada, Pival and Johnson (2004) divulge that they were consulted during the formation of the program. Librarians at the Oregon schools were not part of the initial discussions of creating the OMPH. Nor is the program a fully distance education program.

The collaborative work between OHSU and PSU libraries reflects the existing strategic alliance, the joint degree program, and their involvement with the Orbis-Cascade Alliance. Moreover, the subject librarians at both institutions have an established positive working relationship. Before being appointed at PSU, the PSU librarian was a library faculty member at OHSU. Furthermore, the OHSU librarian is an OMPH student at PSU. This history of collaborative work between the librarians is generates a positive environment for future collaboration between the libraries, and between the librarians and the program.

\section{The Role of Technology}

Second, rapidly evolving technologies seem to make distance program collaborations more feasible. Hope and Peterson (2002) point to this fact.

Rather, the potential of Web-based instruction to transcend the physical space of a specific campus, classroom, or building seems to have provided an impetus for crossinstitutional initiatives; most system-wide or consortium-wide projects and initiatives have in fact focused on the collaborative development of Web-based information literacy instruction (pp. 29-30).

Nothing exemplifies this better than the collaboration of Bermuda College Library in Hamilton, Bermuda, with Mount Saint Vincent University Library in Nova Scotia, Canada. The librarians, Alleyne \& Rodrigues (2011) showcase how technology enabled them to support students enrolled in the joint programs. The librarians used web conferencing technologies to offer online library workshops and orientations for students to learn to use library resources at both institutions. Technology can also be used to make salient what resources and services are available to users. O'Neill and Whitby (2006) discuss this in relation to their work supporting medical staff at collaborating institutions in Great Britain. To this end, librarians created a website that merged the intranets of participating organizations, bringing in information-literacy instruction, tools training, and electronic resources. At PSU and OHSU students and faculty are not clear what resources are available to them and which library policies and practices affect them.

\section{Student and Faculty Needs}

Professional terminal degree programs such as the OMPH attract students from a diverse range of social, educational, and cultural experiences. Because of that student library needs at PSU and OHSU differ. While students at PSU look for large group work spaces, students at OHSU seek quiet refuge 24/7. Students' research needs at OHSU are directly related to health sciences, medicine, and bench science, whereas students at PSU also conduct research in the sciences, liberal arts, humanities, and social sciences.

The following discussion of student and faculty needs is framed solely on personal experience of the librarians. A formal needs assessment has not been conducted, aside from gathering some qualitative feedback via e-mail. 
Inter-Institutional Library Collaboration

\section{Students}

Due to the nature of the OMPH program, and the nature of the city of Portland, many students enrolled in the program are returning and/or part-time students who face more barriers in balancing life and school than do traditional students. Many students may not have conducted research or used an academic library in quite some time. As a result they may need to get refreshing in computer and digital literacy skills, basic mechanical library skills such as requesting books from off-site storage locations, receiving electronic ILL documents, using online catalogs or discovery tools, and even finding a book in the stacks. Further complicating this process is the need to navigate more than one library. For example, a student in OHSU's epidemiology track may be interested in researching traffic intersections in Portland with high incidences of bicycle and motor vehicle accidents. This student may want to use mapping or GIS resources that serve urban planning research at PSU, but are not available at OHSU. In this way, students need to be adaptable, flexible, and ready to learn new research and technology skills.

Since the field of Public Health is interdisciplinary, OMPH students need to use sources from many disciplines. Sources may be primary, secondary, or those that fall into the grey literature category, such as data sets and government documents. Additionally, students need to become familiar with key players in the public health field and to understand concepts such as "evidence-based" and the social contexts in which health sciences research occurs. Although the OMPH program outlines learning competencies for students based on tracks of study, learning outcomes emphasized by librarians, neither ACRL's Information Literacy Standards (2000) nor locally-developed library learning outcomes-- are wholly reflected in track learning competencies.

\section{Faculty}

The faculty serving the OMPH program comprises full-time faculty members at all three institutions, and adjunct teaching faculty who work in the public health field in the state. They are all are granted affiliate status at program partner institutions, yet many professors are not aware of this fact, nor do they understand how to access affiliate institutional resources. One contributing factor might be process and policy differences between the libraries. For example at OHSU, staff, faculty and students need to apply to get a library barcode, whereas at PSU and OSU, a network account serves as one's library credentials.

Faculty may also need to be introduces to new library research tools and methodologies. Particularly so they can pass on necessary library research skills and information literacy skills to students. Although several learning competencies for the OMPH program include words such as "analyze," "evaluate," and "assess," faculty may not be aware that these are skills that librarians can impart to students.

\section{The Library Collaboration}

Historically, library collaboration in support of the OMPH has been disjointed due to lack of formalized efforts between the libraries and a series of administrative and staff transitions. However, as the involved institutions embark on other collaborative ventures, there has been an impetus to strengthen existing ties and formalize library support and service to this program.

In 2011, several librarians from OHSU and PSU met with the OMPH Program Director to discuss library issues and the program's future after OSU's impending separation. The group identified several areas in which to move forward, namely collections, instruction, and administrative support. 
Inter-Institutional Library Collaboration

1. Collections librarians were charged with assessing titles in a consortial Springer journal package for complete coverage. Since both collections librarians were already involved in the Orbis-Cascade Alliance's discussions regarding its Springer journals package this work was logical and simple.

2. Liaison librarians were charged with creating a library research guide for OMPH students and the coordination of in person instruction. Both institutions had recently acquired Springshare's LibGuides software.

3. University Librarians were charged to work with the OMPH Program Director to advise on broad-scale library issues. To that end, University Librarians worked to ensure that librarians received affiliate faculty status at partner institutions in order to access library resources at the other institution. Moreover, they would advise the OMPH Program Director regarding library issues that could be resolved in the Memorandum of Understanding (MOU) which was being drafted and would take effect in 2014.

\section{Library Access Issues}

One of the major challenges for students in the OMPH program is accessing library resources at partner institutions. Students are matriculated through one of three institutions, earning them library privileges at the institution in which they are matriculated. However, students are not extended library privileges at partner libraries. Instead, they are treated as visitors. For example, OHSU students OHSU may not remotely access Portland State University library databases, and vice versa. Instead, students must travel in person to their partner libraries to use database subscriptions and other library resources.

Michael and Balraj (2003) point to the value of combined library resources that serve joint degree programs, "With a joint degree program, two bodies of faculty, library resources, and other institutional resources are combined and made available to students of the programs, therefore increasing the wealth and quality associated with these programs" (p. 135). What the authors fail to acknowledge, however, are that institutional policies and licensing problems can introduce access barriers.

Although cross-institutional enrollment exists, this does not translate to access to the same resources all the time. Current OMPH students are eligible to enroll in classes at any of the three institutions for core and elective courses, though most of the cross-enrollment occurs between OHSU and PSU. Despite cross-enrollment, students do not receive access to the same library resources. Students are treated as library visitors at institutions that are not their home institutions. The result of this program policy is a lack of remote access to library resources. This is simply one example of the challenges facing students, faculty, and staff affiliated with the OMPH program.

Likewise, computing at the PSU library poses challenges to students matriculated through OHSU. While both institutions offer public access computing stations, their implementations differ. Portland State University uses a "white list" system for websites and resources accessible via public access kiosk computers, whereas OHSU offers the open web on its stations. Further, non-OHSU affiliated patrons may use the OHSU wireless connection, whereas at PSU, wireless access requires authentication with PSU credentials. Although there does exist a process for allowing guest researchers to access the wireless, there are only a small number of individuals in the library facility who are able to generate guest wireless accounts, which are active for only 12 hours. Those individuals who may make guest wireless accounts at the PSU library have been granted permission to do so by the campus IT department. Situated in downtown Portland and with existing computer lab capacities reaching or exceeding their maximum with regularity, 
these PSU policies are intended to serve PSU students. However, in this case, complex bureaucratic structures impede PSU library access to students matriculated in the OMPH program through OHSU.

With a new MOU being drafted, librarians remain hopeful PSU and OHSU will come to mutual understanding to create affiliate accounts for OMPH students, and that these accounts will function for students' duration in the program, not just the duration of cross-enrollment. While librarians and library administrators have provided input as to the barriers in access, the MOU process is largely an administrative process that happens outside of the library's purview. We are lucky to have been able to provide input in this matter.

OHSU and PSU have just begun to build their collaborative relationships. Due, in part, to the subject liaison's experiences with the OMPH program, and administrative support at both institutions to pursue collaboration, the libraries are well positioned to effect positive changes that will improve the library research experience for both students and faculty of the OMPH. We expect to encounter challenges along the way, but the experience gained in current projects will lead to future projects and improvements to library service for the OMPH program.

\section{Creating a LibGuide}

Creating a shared research guide for students was one of the first collaborative projects between the OHSU and PSU libraries to support the OMPH program. In addition to serving a well-known need, it was a good venue in which to discover and discuss administrative and technical challenges to collaboration between the two libraries. The rest of this chapter presents a case study about the creation of a library research guide for OMPH students and faculty in Portland.

\section{Methodology}

To gather input regarding content and structure of LibGuide, students and faculty were asked for input via e-mail. Initially, OMPH students who had worked with the PSU subject librarian were approached either via e-mail, or an in person consultation, as were PSU faculty members who taught courses in the program. They responded to open ended questions about what they would like to see on a web-based research guide. Then general feedback was solicited on the OMPH listserv, the guide content and what would help to navigate the two libraries.

After receiving this qualitative feedback from 10 individuals, data were used to inform the creation of an online card sorting activity. Card sorting is a usability method that enables researchers to understand users' mental models of information organization. In a card sort study, participants are asked to group ideas or labels (typically written on index cards) into categories that make sense to them. Since our patrons are mostly busy working professionals who attend school part-time, it was decided to conduct an online card sorting activity using a third party vendor, Optimal Workshop's OptimalSort, an online card sorting tool, was used to identify categories of information, their organization and to identify logical naming conventions for information.

Usability expert Jakob Nielsen (2004) asserts that in card sort activities, the optimal number of subjects is 15 . Unfortunately only 10 responses were received for this activity, partly due to the poor timing of the study during the school quarter.

Librarians normalized the data and created a wireframe based on analysis of the card sort activity. Additional feedback was solicited from through the OMPH listserv about the wireframe. Subsequently, the LibGuide was created first in PSU's website, and then copied and slightly modified in OHSU's. Due to technological inability the guide is embedded within two disparate 
Inter-Institutional Library Collaboration

websites and hosted on separate servers. Although having two instances of this guide creates the need for ongoing collaboration it is important that students and faculty access research resources within the context of their home institution's website.

\section{Challenges}

Throughout the research process, many challenges were encountered. First, the process to gain human subject testing exemption and waivers through the Institutional Review Board (IRB) was onerous. The PSU librarian underwent the IRB process first, and was informed that human subjects exemptions shared between PSU and OHSU occurred regularly with quick turnaround. PSU's process took 2.5 weeks and OHSU's took over 2 months. Other challenges encountered included:

- Most individuals providing feedback via e-mail and participating in the card sort study were PSU affiliated

- Poor timing in the academic year to maximize study participation

- A disconnect with OSU students and faculty and differing technological research guide systems employed by OSU than that used by OHSU and PSU.

\section{The Guides}

Based on the e-mail feedback received and the card sort analysis, librarians built a guide that reflected content desired from students and faculty. To this end, the guides include instructional content; citation management guidance; explanation of library and computing access at home and affiliate institutions; and frequently used databases for public health and public health specialties.

Differences between the two guides are minimal. However, those that do exist result from the different technological implementations, or choices made by the librarians to highlight resources at "home" institutions. For example, on the home page of each guide one can see several stylistic differences. The most obvious are color and formatting. Additionally:

- PSU's implementation replicates its library web site, incorporating the same menu as on any other library web page.

- OHSU's implementation includes a description of the guide.

- PSU's implementation includes other related guides at the institution, reflecting the two schools in which MPH students may be enrolled at the institution.

\section{TAKE IN FIGURE $1 \& 2$}

Although librarians are highlighted differently on each guide, being listed first on the guide she owns, most intentional differences between the two guides occur "behind the scenes." Good examples are the links from book cover images on the Topics in Public Health page; these links were customized for each institution since the libraries do not use the same online public access catalogs and do not have the same monograph holdings. This page is also a good example showing resources that support public health specialties. Where PSU's database subscriptions include Social Services Abstracts and Sociological Abstracts, which may be useful to students studying health disparities and social determinants of health, OHSU subscribes to the Global Health database, which supports students studying international health.

TAKE IN FIGURES $3 \& 4$ 
Another manner in which the guide delineates between PSU and OHSU subscribed resources is by using visual cues. On the Library Specific Access and Data Sources, Databases, \& Articles pages, logo banners highlight which box and column address PSU and OHSU.

\section{TAKE IN FIGURE 5}

While these differences seem slight, they are not easily managed. Each time one of the librarians makes a change to her guide, she must coordinate with her counterpart to make the same or similar change. This occurs when new resources are acquired or when library policies and procedures change.

\section{Promotion}

The librarians did not assume that producing a guide would automatically mean it would be used. Instead, librarians have made efforts to promote the resource to students and teaching faculty. Students at orientations received a promotional bookmark with the guides' URLs and librarians showcase the guide in the classes they teach for OMPH students. Another useful promotion tool is the integration of LibGuides into the Desire2Learn course management system at PSU. Using a script written by the PSU Library's programmer, a link to the research guide will appear in course shells for each core MPH course taught at PSU.

O’Neill and Whitby (2006) discuss their raised profile and increased library service demand after deploying a resource for their communities. Already have discussions between the OMPH program and librarians serving students in Portland resulted in positive relationships. As a result, the OMPH Program Coordinator scheduled time for the librarians to be present at the program orientation, and asked for guidance about the library information included in the OMPH student handbook. We expect OMPU user demand to grow, as the community learns of the resources available (and not available) to them.

\section{Conclusion}

OHSU and PSU are at an exciting developmental stage of library collaboration. Librarians serving the OMPH program have discovered numerous opportunities to better serve students and faculty, and have identified challenges to address in order to improve the quality of student and faculty library experiences. Resolving library access issues for OMPH students remains a high priority for administrative teams at each institution and the libraries remain hopeful that a new MOU for the OMPH program will alleviate these problems. Inter-institutional library collaboration is most successful when library and other administrations at institutions of higher learning are committed to building collaborations that address libraries' unique needs, and when administrators provide support for the librarians doing the on-the-ground work.

In the process of developing and implementing a LibGuide, the librarians discovered that, in addition to solving library access issues, students in the OMPH program need to better acquire library and research skills, including critical thinking about information and research. Aside from the challenge of getting user input to inform the guide's development, the librarians remain dedicated to serving students and faculty in this collaborative inter-institutional joint degree program. 
In the future the librarians will collaborate to further support instruction, collection development, and other library issues for the OMPH. They will work to develop library workshops for students finishing the program (So now that I'm done with my MPH, how do I research?), and to develop more comprehensive learning objects that speak to the track learning competencies and library learning outcomes. 
Inter-Institutional Library Collaboration

\section{References}

Alleyne, J. M., \& Rodrigues, D. (2011). Delivering information literacy instruction for a joint international program: An innovative collaboration between two libraries. College \& Undergraduate Libraries, 18(2-3), 261-271. doi:10.1080/10691316.2011.577697

Association of College \& Research Libraries. (2000). Information Literacy Competency Standards for Higher Education. Community \& Junior College Libraries (Vol. 9). Chicago,IL. Author. Retrieved from http://www.ala.org/acrl/sites/ala.org.acrl/files/content/standards/standards.pdf doi:10.1300/J107v09n04_09

Denecke, D. D., Kent, J. D., Anderson, G., \& Council of Graduate Schools in the United States. (2010). Joint degrees, dual degrees, and international research collaborations: A report on the CGS Graduate International Collaborations Project. Washington, DC: Council of Graduate Schools.

Hope, C. B., \& Peterson, C. A. (2002). The sum is greater than the parts: Cross-institutional collaboration for information literacy in academic libraries. Journal of Library Administration, 36(1-2), 21-38. doi: 10.1300/J111v36n01_03

Kezar, A. J., \& Lester, J. (2009). Organizing higher education for collaboration: A guide for campus leaders. San Francisco, CA: Jossey-Bass.

Learning Alliance for Higher Education. (2007, June 1). Considering the possibility of merging Oregon Health \& Science University and Portland State University: A report to The Oregon University System. West Chester, PA: Author. Retrieved from http://former.ous.edu/news_and_information/news/files/OUSReport_TLA_FINAL_6-1$\underline{07 . p d f}$

LibGuides. (n.d.). [Software and Server]. Miami, FL: SpringShare. http://springshare.com/libguides/Michael, S. O., \& Balraj, L. (2003). Higher education institutional collaborations: An analysis of models of joint degree programs. Journal of Higher Education Policy and Management, 25(2), 131-145. doi:10.1080/1360080032000122615

Nielsen, J. (2004, July 19). Jakob Nielsen's Alertbox: Card sorting: How many users to test. Retrieved from http://www.useit.com/alertbox/20040719.html

OHSU-PSU Strategic Alliance Advisory Committee. (2012, May 30). Implementation Committee report [PowerPoint slides]. Portland, OR: Author. Retrieved from http://www.pdx.edu/president/sites/www.pdx.edu.president/files/OHSU_PSU_Advisory FINAL_5_30_12.pptx 
Inter-Institutional Library Collaboration

OHSU/PSU Strategic Partnership Task Force. (2011, January 5). OHSU / PSU Strategic Partnership Task Force report. Portland, OR: Author. Retrieved from http://pdx.edu/sites/www.pdx.edu.president/files/OHSU-PSU\%20ReportFinal.pdf.pdf

O’Neill, A., \& Whitby, S. (2006). Stepping out: The changing role of e-resources librarians. Health Information and Libraries Journal, 2 (Suppl 1), 54-57. doi:10.1111/j.14711842.2006.00679.x

OptimalSort. (n.d.). [Software and web service]. Wellington, New Zealand: OptimalWorkshop. http://www.optimalworkshop.com/

Oregon Health \& Science University. (2011). OHSU at a glance. Retrieved from http://www.ohsu.edu/xd/about/upload/OHSU_At_a_Glance.pdf

Oregon Master of Public Health. (2009). Ranking. Retrieved from http://oregonmph.org/content/ranking

Pival, P. R., \& Johnson, K. (2004). Tri-institutional library support: A lesson in forced collaboration. Journal of Library Administration, 41(3/4), 345-354. doi:10.1300/J111v41n03_01

Portland State University, Office of Institutional Research and Planning. (2010). Student Profile Total Enrollment, Fall $20104^{\text {th }}$ Week [Data file]. Portland, OR: Author. Retrieved from http://www.oirp.pdx.edu/source/port1011/all_all.htm

Portland State University, Office of Institutional Research and Planning. (2011). Common Data Set [Data file]. Portland, OR: Author. Retrieved from http://www.oirp.pdx.edu/common_data_set/CDS.pdf\#i

\section{Figures}

Figure 1: OHSU Guide Home Page 


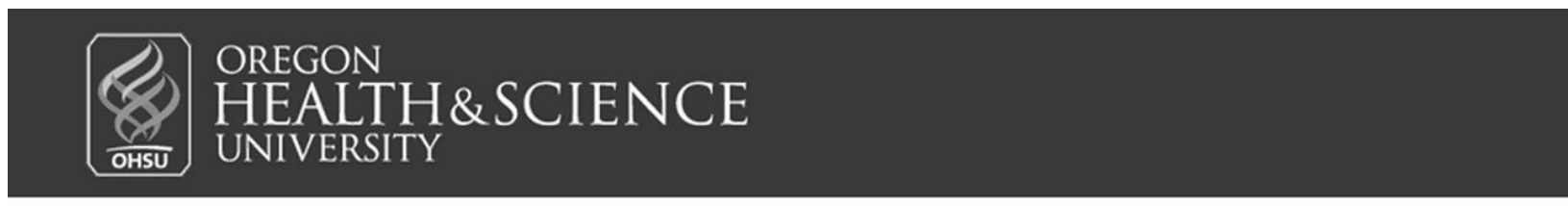

OHSU Library » LibGuides » Oregon MPH

Admin Sign In

Oregon MPH

This is the OHSU version of the Oregon MPH (Master of Public Health) program LibGuide, created by Emily Ford (PSU) and Laura Zeigen (OHSU)

URL: http:/libguides.ohsu.edu/omph B B Print Guide QRSS Updates SHARE

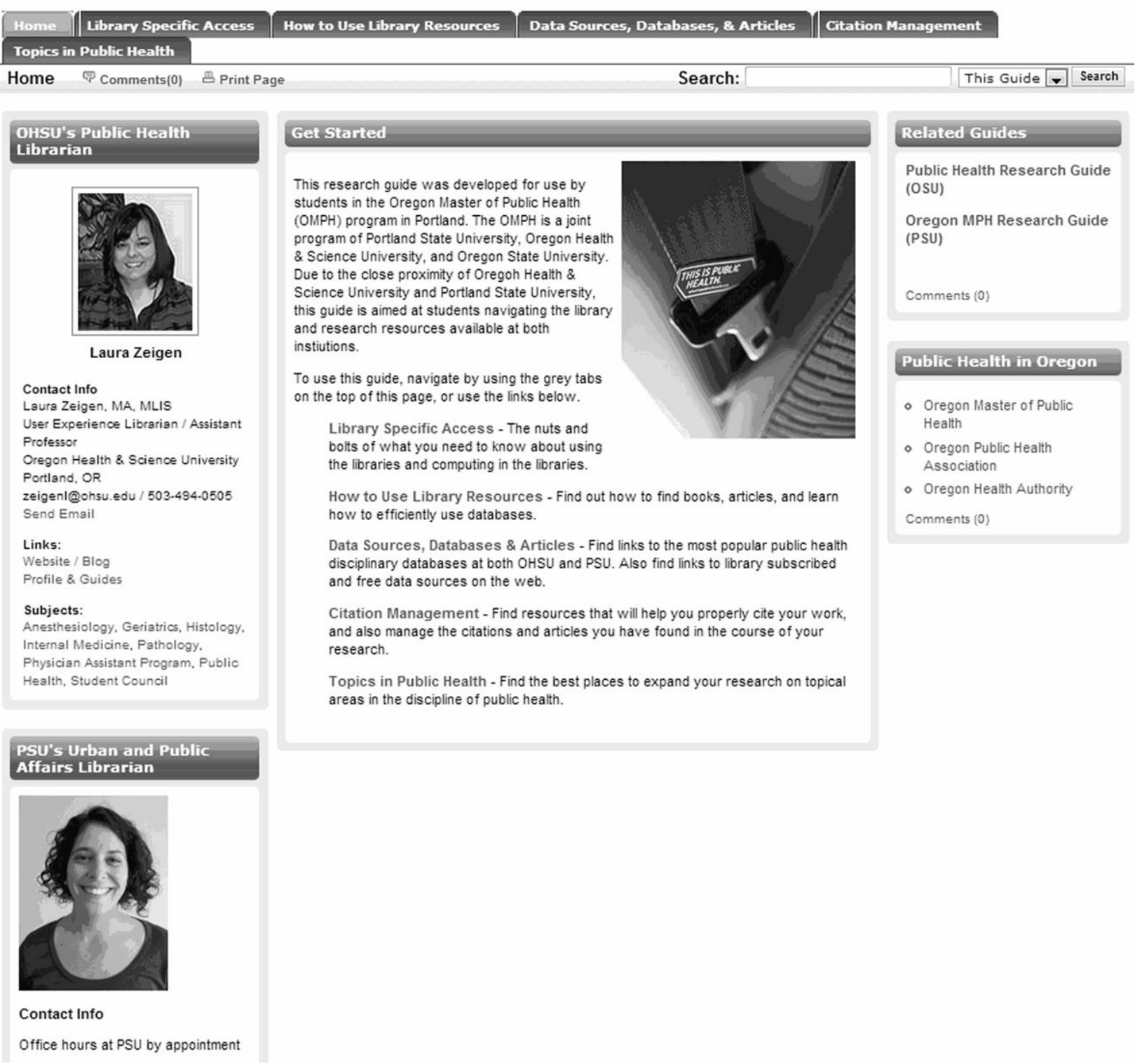

Figure 2: PSU Guide Home Page 


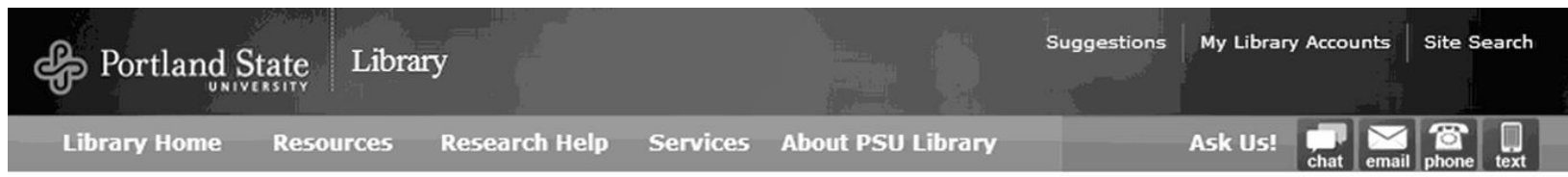

\section{Oregon MPH}

Home B Print Page

PSU's Public Health Librarian

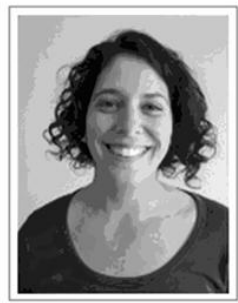

Emily Ford

\section{Contact Info}

Office Hours by Appointment forder@pdx.edu

503-725-3689

Links:

Profile \& Guides

\section{OHSU's Public Health} Librarian

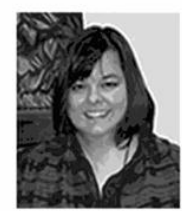

\section{Laura Zeigen}

\section{Contact Info}

zeigenl@ohsu.edu

503-494-0505

\section{Get Started}

This research guide was developed for use by students in the Oregon Master of Public Health (OMPH) program in

Portland. The OMPH is a joint program of Portland State University, Oregon Health \& Science University, and Oregon State

University. Due to the close proximity of Oregoh Health \& Science University and Portland State University, this guide is aimed at students navigating the library and research resources available at both instiutions.

To use this guide, navigate by using the grey tabs on the top of this page, or use the links below.

Library Specific Access - The nuts and bolts of what you need to know about using the libraries and computing in the libraries.

How to Use Library Resources - Find out how to find books, articles, and learn how to efficiently use databases.

Data Sources, Databases \& Articles - Find links to the most popular public health disciplinary databases at both OHSU and PSU. Also find links to library subscribed and free data sources on the web.

Citation Management - Find resources that will help you properly cite your work, and also manage the citations and articles you have found in the course of your research.

Topics in Public Health - Find the best places to expand your research on topical areas in the discipline of public health.

\section{Related Guides}

- Oregon MPH Research Guide (OHSU)

- Public Health Research Guide (OSU)

- Public Administration by Emily Ford

- Community Health by Emily Ford

\section{Public Health in Oregon}

- Oregon Master of Public Health

- Oregon Public Health Association

- Oregon Health Authority

\section{Figure 3: Health Promotion Health Topic Box}


Inter-Institutional Library Collaboration

\section{Health Promotion}

When researching for health promotion topics, consider using keywords related to the topic. For example:

education

consumer health

community health services

ERIC (PSU) 6

Teaching, learning, schools, educational policy; article citations, full text of non-peer

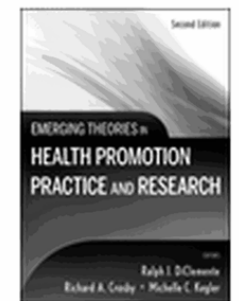
reviewed documents.

ERIC (OHSU)

The world's premier database of journal and non-journal education literature. A database of more than 1.1 million citations going back to 1966 , including more than 107,000 full-text nonjournal documents issued between 1993-2004.

Health Source: Consumer Edition (PSU) a

Article citations and many full text articles from popular health and medicine journals.

Health Source: Consumer Edition (OHSU)

Provides full text for over 280 health periodicals, nearly 1,200 health pamphlets, and 20 health reference books.

Consumer Health Research Guide

A consumer health research guide developed by OHSU Librarians.

\section{Figure 4: Topics in Public Health Page}


Inter-Institutional Library Collaboration

Topics in Public Health

On this page

- Books on Public Health (PSU)

- Books on Public Health (OHSU)

- Researching Public Health Topics

- Environmental Heatlh \& Safety

- Epidemiology \& Biostatistics

- Health Disparities \& Social Determinants of Health

- Health Management \& Policy

- Health Promotion

- International Health

- Occupational Health

Books on Public Health (PSU)

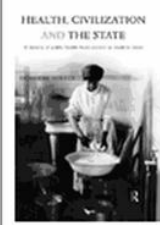

Political History of Public Health - Dorothy Porter ISBN: 9780415122443 Publication Date: 1999-0106

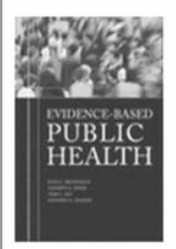

Evidence-Based Public Health - Ross C. Brownson (Editor); Elizabeth A. Baker (Editor); Terry L. Leet (Editor); Kathleen $\mathrm{N}$. Gillespie (Editor)

ISBN: 9780195143768

Publication Date: 2002-0919

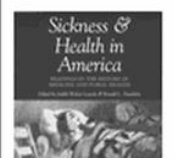

B Print Page

\section{Researching Public Health Topics}

In addition to using the databases listed on the Data Sources, Databases \& Statistics page of this guide, you may want to use specific resources for searching in some topical areas related to public health. See the resources listed below.

\section{Environmental Health 8 Safety}

When research for environmental health topics, consider using keywords related to the topic. For example:

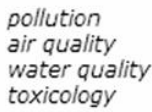

Databases from the National Library of Medicine on toxicology, hazardous chemicals, environmental health, and toxic releases. Access is free on the web.

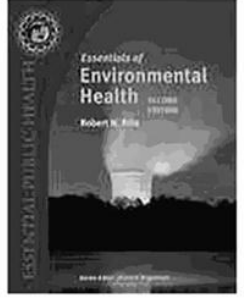

Environment Complete (PSU) 0

Covers areas of agriculture, ecosystem ecology, energy, renewable energy sources, natural resources, marine \& freshwater science, geography, pollution \& waste management, environmental technology, environmental law, public policy, social impacts, and urban planning.

\section{Epidemiology \& Biostatistics}

When researching epidemiological and biostatistics health topics, consider using keywords related to the topic. For example:

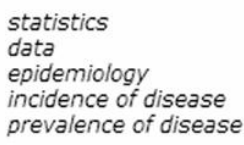

\section{Health Disparities \& Social Determinants of Health}

When researching the social determinants of health, consider using keywords related to the topic. For example:

equity

social justice

justice

Social Services Abstracts (PSU) 0

Citations to research focused on social work, human services, social welfare, social policy, and community development.

Sociological Abstracts (PSU) a

Citations to the international literature in sociology and related disciplines in the social and behavioral sciences.

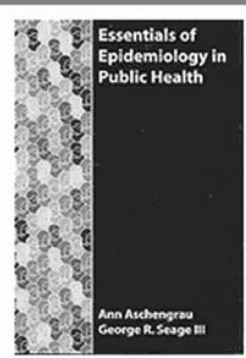

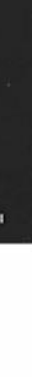

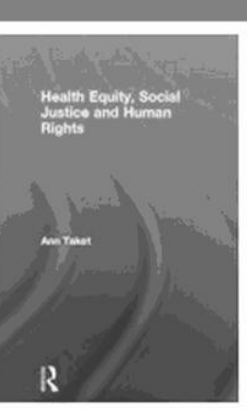

Figure 5: Data Sources, Databases \& Articles Page 
Inter-Institutional Library Collaboration

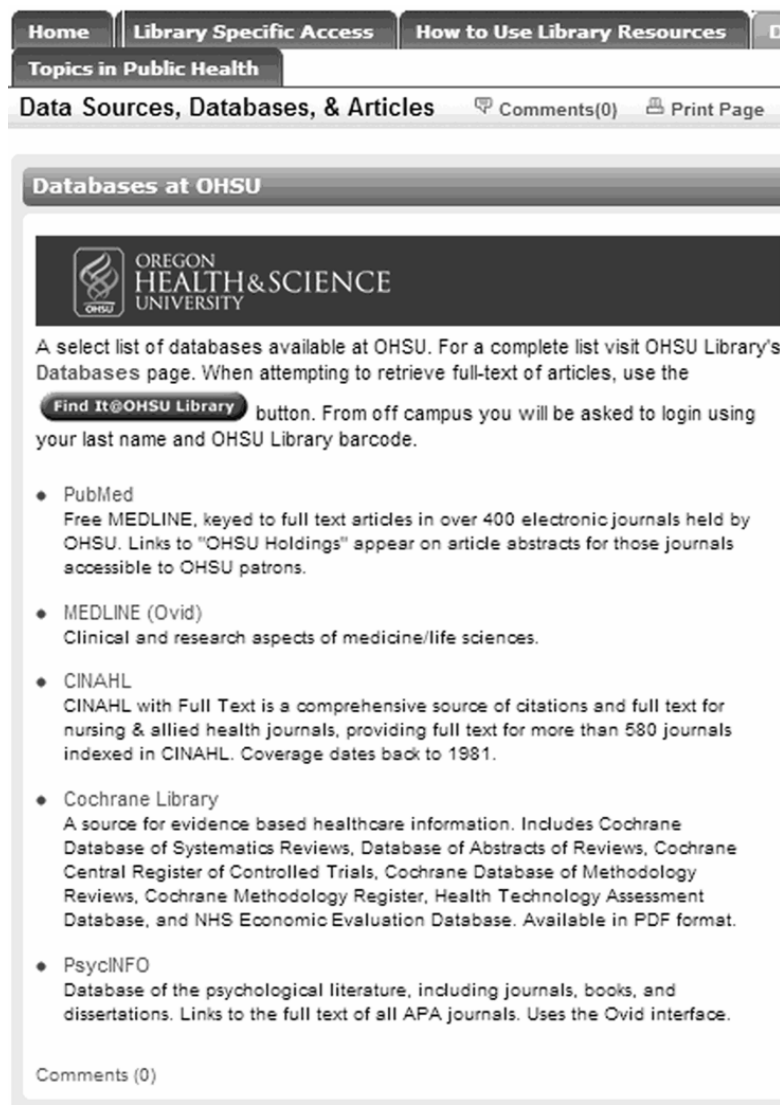

\section{Databases at PSU}

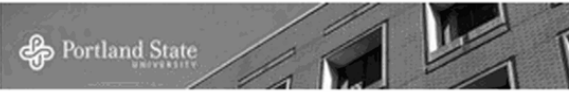

A select list of databases available at PSU. For a complete list visit PSU Library's Databases page. When attempting to retrieve full-text articles, click on the Find It @ PSU button. From off campus you will be asked to login with your ODIN account to access these databases. You may also wish to view the Community Health research guide for further database suggestions.

- Publled (Interface for MEDLINE) (0 Citations and abstracts for journal articles in all areas of medical practice and research

- MEDLINE (Ovid Interface) Citations and abstracts for journal articles in all areas of medical practice and research.

- Ageline 6 Contains citations and abstracts to journal articles and other materials regarding issues related to aging.

- Health Source: Nursing/Academic edition 6 Article citations and many full text articles from health and medicine journals

- Cochrane Library 6

Comprised of full text, evidence-based reviews of clinical trials and heslthcare/medical interventions.

- PsyclNFo 0 Citations and abstracts for journals, books and dissertations in psycholog; and human behavior.

- Sage Research Methods Online (1) Contains full text Sage research methods books, handbooks, and enoydopedias. Videos and interactive mapping tools are available. 


\section{Tables}

Table 1

OMPH Tracks of Study

\begin{tabular}{|l|c|l|}
\hline Track & $\begin{array}{l}\text { Total Required } \\
\text { Credit Hours }\end{array}$ & Institution \\
\hline $\begin{array}{l}\text { Epidemiology \& Biostatistics } \\
\text { Combined }\end{array}$ & 60 & Oregon Health \& Science University \\
\hline Environment, Safety \& Health & 59 & Oregon State University \\
\hline Health Management \& Policy & 61 & $\begin{array}{l}\text { Oregon State University, Portland } \\
\text { State University }\end{array}$ \\
\hline Health Promotion & 59 & $\begin{array}{l}\text { Oregon State University, Portland } \\
\text { State University }\end{array}$ \\
\hline International Health & 62 & Oregon State University \\
\hline $\begin{array}{l}\text { Primary Care \& Health Care } \\
\text { Disparities }\end{array}$ & 58 & $\begin{array}{l}\text { Oregon Health \& Science University } \\
\text { (online) }\end{array}$ \\
\hline Biostatistics & 60 & Oregon State University \\
\hline Epidemiology & 60 & Oregon State University \\
\hline
\end{tabular}

\section{Table 2}

Stages of Collaboration Development in Higher Education

\begin{tabular}{|l|l|l|}
\hline $\begin{array}{l}\text { Stage 1: Building } \\
\text { Commitment }\end{array}$ & Stage 2: Commitment & $\begin{array}{l}\text { Stage 3: Sustaining } \\
\text { Commitment }\end{array}$ \\
\hline $\begin{array}{l}\text { External pressure } \\
\text { learning } \\
\text { values } \\
\text { networks }\end{array}$ & $\begin{array}{l}\text { Mission } \\
\text { networks } \\
\text { rewards }\end{array}$ & $\begin{array}{l}\text { Integrating structures } \\
\text { rewards } \\
\text { networks }\end{array}$ \\
\hline
\end{tabular}

